\title{
Seasonal and spatial variation in the diet of the wild rabbit (Oryctolagus cuniculus L.) in Portugal
}

\author{
H. Martins ${ }^{1,2 *}$; J. A. Milne ${ }^{1}$ and F. Rego ${ }^{2}$ \\ ${ }^{1}$ Macaulay Land Use Research Institute, Craigiebuckler, Aberdeen AB15 8QH, U.K. \\ ${ }^{2}$ Applied Ecology Centre Professor Baeta Neves, Tapada da Ajuda, 1349-018 Lisbon Codex, Portugal \\ (Accepted 15 January 2002)
}

\begin{abstract}
The seasonal and spatial pattern of diet composition of a population of wild rabbits Oryctolagus cuniculus L. occupying a southern Portuguese montado was estimated using the $n$-alkane technique. The diet was analysed in terms of components that are relevant to habitat management. The dietary categories considered were gum cistus leaves and flowers, cork oak and holm oak seedlings and acorns, cereals, olive tree regrowth and grass-forb species. The objectives were to assess the changes in diet across seasons in relation to the reproductive cycle of the rabbits, and to relate these changes to herbaceous biomass availability and to habitat structure, in terms of density of scrub cover and accessibility to arable crops. The results demonstrated that the diet was dominated by grass-forbs, and cereals when they were available. Browse was an important component of the diet and became more important in a year of low herbaceous biomass availability and in areas dominated by dense scrub. A similar phenomenon was observed in relation to consumption of acorns in winter. Seasonal and spatial variation in diet composition suggested a strategy aimed at maintaining a high quality diet. This was supported by the observed high dry matter digestibility of the diet during most of the year. The relevance of growing arable crops and providing fodder, as a means of increasing the carrying capacity of montados for rabbits and protecting the natural regeneration of trees, is discussed.
\end{abstract}

Key words: Oryctolagus cuniculus, diet, habitat, biomass, variation

\section{INTRODUCTION}

The feeding behaviour of the wild rabbit Oryctolagus cuniculus L. is characterized by being selective and opportunistic. Across a range of habitats, in different geographic regions, it has been established that the diet composition of rabbits changes seasonally and spatially, according to plant species availability, their phenological development and their nutritive value (Williams, Wells \& Wells, 1974; Bhadresa, 1977; Chapuis, 1979; Soane, 1980; Chapuis \& Forgeard, 1982; Soriguer, 1988). However, these changes in diet have not been studied so far in the montados, savanna-like ecosystems, dominated by cork oak and holm oak, which are of great ecological and economic interest in Portugal (e.g. Joffre, Rambal \& Ratte, 1999; Roberts \& Nunes da Silva, 2000).

Changes in agriculture in Portugal in the past decade have resulted in a reduction in the importance of cereal

*All correspondence to: H. Martins, Applied Ecology Centre Professor Baeta Neves, Agronomy Institute of Lisbon, Tapada da Ajuda, 1349-018 Lisboa Codex, Portugal.

E-mail: ceabn@ip.pt production in montados, making these systems dependent, for example, on alternative livestock production systems and hunting (see, for example, Barreto \& Carvalho, 1993; Alves et al., 1995). As a result of the decrease of indigenous wild rabbit populations in the Iberian Peninsula, caused by habitat changes, disease, excessive predation and hunting (e.g. Moreno \& Villafuerte, 1995; Moreno et al., 1996; Palomares, Calzada \& Revilla, 1996), management techniques are required if the populations are to be maintained.

Quantitative assessment of the major components of the diet should provide valuable information for the estimation and improvement of the carrying capacity of montados for rabbits. However, the impact of rabbits on the natural regeneration of oak stands, arable crops and on natural vegetation, as well as the competition with other herbivores, also have to be taken into consideration in developing a management plan.

In order to provide information on how to achieve a sustainable exploitation of wild rabbit in montados, this study presents quantitative estimates of the diet composition of a rabbit population in a Southern Portuguese montado using the $n$-alkane technique. The diet was 
analysed by separating food items into groups most relevant in terms of habitat management, namely scrub (gum cistus Cistus ladanifer L.), cork oak and holm oak seedlings, cork oak and holm oak acorns, cereals, regrowth of olive trees Olea europaea var. europaea L. and grass-forbs. The importance of these groups in the diet was analysed seasonally over two annual cycles in different habitats, and related to herbaceous biomass availability. The main objective was to assess whether changes in the overall diet, and in consumption of oak regeneration in particular, were related to seasonal changes in primary production. The relevance of introducing arable crops as a management strategy to improve the carrying capacity of the estates for rabbits and to protect natural regeneration is also discussed.

\section{METHODS}

\section{Study area}

The study area was a 270-ha hunting estate in southeast Portugal $\left(38^{\circ} 47^{\prime} \mathrm{N}, 7^{\circ} 25^{\prime} \mathrm{W}\right)$, comprising a rolling landscape between 300 and $420 \mathrm{~m}$ altitude. The climate is Mediterranean with a strong seasonality of hot, dry summers (average temperature of $25^{\circ} \mathrm{C}$ with an average rainfall of $2 \mathrm{~mm}$ in August) and rainy, mild winters (average temperature of $9^{\circ} \mathrm{C}$ with an average rainfall of $100 \mathrm{~mm}$ in January) (Rosário et al., 1983).

The vegetation consists mainly of cork oak Quercus suber L. and holm oak Quercus rotundifolia L. stands, some of them undersown with crops of triticale $\times($ Triticosecale Wittmack and oats Avena sativa $\mathrm{L}$. The remaining understorey is dominated either by patches of gum cistus or natural pasture. The open structure of the oak stands is characteristic of savanna-like forest ecosystems in the southern regions of Portugal, herein referred as montados.

Olive trees are also found, especially in the crop fields. Amongst the 120 different herbage species identified in the natural pasture, the most abundant are Agrostis pourretii Willd., Bromus hordeaceus L., Echium plantagineum L., Leontodon taraxacoides (Vill.) Mérat, Ornithopus compressus L., Rhagadiolus stellatus (L.) Gaertner, Trifolium angustifolium L. and Vulpia geniculata (L.) Link.

\section{Definition of the collection sites}

Vegetation and faecal samples were collected from 16 groups of warrens. An area was defined around each group that would reflect the foraging range of the rabbits belonging to the same group of warrens. In order to assess this area, hereafter called collection site, observations of crepuscular movements were carried out using a focal sampling method (Martin \& Bateson, 1993). In a total of 37 periods of observation (lasting $1 \mathrm{~h}$ at dusk) with 53 individuals observed, the average distance travelled was $30.2 \mathrm{~m}(\mathrm{SEM}=0.33)$ and the greatest distance was $74 \mathrm{~m}$. A radius of $100 \mathrm{~m}$ around each group of warrens was, therefore, established as the probable range within which most of the foraging activity occurred. This was also the maximal dispersion observed by Gibb (1993) for both sexes.

\section{Sample collection}

Vegetation and faecal samples were collected within the collection sites for 2 years, 1998 and 1999, and in each of the 3 seasons defined by Alves \& Moreno (1996) as reflecting the reproductive biology of the species in the study area. These were designated as the breeding season (between January and June), the post-breeding season (between July and September) and winter (between October and December). There were 2 sample collections in the middle of each season, with an interval of 2 weeks between them.

Faecal samples were collected in the proximity of warrens belonging to the same collection site. Plant species for $n$-alkane analysis were collected randomly over the study area at the same time as faecal samples, as suggested by Dove \& Mayes (1991). The plant species collected were selected on the basis of being abundant at each collection site, showing signs of being consumed and being potentially important as a seasonal feed resource, such as gum cistus flowers and acorns. No attempt was made to identify the importance of specific parts of the plant species in the diet and, therefore, the whole plant was included in the analysis, with exception of gum cistus for which only flowers and leaves were considered.

Patches of the different vegetation types within the collection sites were delimited on an orthophotomap and their areas were measured using ArcView 3.1 (ESRI, 1995). Five different vegetation types were considered: arable crops, pasture, low scrub, average scrub and tall scrub. Random $20 \times 40 \mathrm{~cm}$ quadrats, in numbers proportional to the area of the patches, were used to measure percentage of cover and average height of the total vegetation, contemporaneously to the collection of faecal samples. Between 6 and 24 quadrats were used to sample vegetation patches with areas from 0.07 to 7 ha. A total of 1080 quadrats were sampled per season. One third of the quadrats was clipped to ground level and the biomass dried at $60^{\circ} \mathrm{C}$ for $48 \mathrm{~h}$ and weighed. The dry matter estimates obtained in this way were regressed against the volume $(\%$ of cover $\times$ average height) and the relationship used to predict the biomass of the remaining quadrats. This double sampling strategy was followed to reduce the effort of estimating the herbaceous biomass availability (Thompson, 1992).

The availability of both holm oak and cork oak acorns was assessed in winter by ground counts in $20 \times 1 \mathrm{~m}$ plots (Gysel, 1956), randomly distributed within the vegetation patches at each collection site, in numbers proportional to their area. Between 2 and 7 plots per vegetation patch were counted and 125 plots were counted in all in each year. 


\section{Composition of the diet}

Particular patterns of concentrations of $n$-alkanes in cuticular wax are specific to individual plant species (Dove, Mayes \& Freer, 1996; Bugalho, 1999; Chen et al., 2000) or parts of plants (Dove et al., 1996). Therefore, there is potential for them to be used as markers in the estimation of diet composition from the pattern of $n$-alkane concentrations in the faeces, assuming that they are fully recovered or, if faecal recoveries are incomplete, that relative recoveries are known (Dove \& Mayes, 1991). The usual method for estimating diet composition from the pattern of $n$-alkanes in faeces and in plant species is based on a least-squares procedure using the available $n$-alkanes (Salt, Mayes, Colgrove et al., 1994; Dove \& Moore, 1995; Mayes, Dove et al., 1995).

All samples of plant species and faeces for $n$-alkane analysis were oven-dried at $60^{\circ} \mathrm{C}$ for $48 \mathrm{~h}$ and milled through a $1-\mathrm{mm}$ mesh. The ground samples were analysed for $n$-alkane concentrations using gas chromatography, according to the method described in Mayes, Lamb et al. (1986) with the modifications reported in Salt, Mayes \& Elston (1992). The concentrations of all $n$-alkanes between $\mathrm{C}_{21}$ and $\mathrm{C}_{35}$ were determined, with exception of the concentrations of $\mathrm{C}_{22}$ and $\mathrm{C}_{34}$ because they were used as internal standards. The concentration of each $n$-alkane was corrected for its recovery in the faeces (Martins, Elston et al., in press).

The focus for the quantification of the diet was the importance of dietary components that would be relevant for habitat management in montados, either to encourage an increase in the rabbit population or to reduce their impact on the vegetation. Diet composition was, therefore, assessed from the proportion of cork oak and holm oak seedlings, acorns of both species (only available in winter), regrowth of olive trees, gum cistus leaves and flowers (only available in the breeding season), cereals (available all year but only as stubble in winter), and a grass-forb group.

A mixture of plant species was selected as being representative of the grass-forb group, which differed slightly for each collection site and in each season. The plant species were selected using information on their local frequency obtained from the quadrats, and the likelihood of their being present in the diet. This was inferred from the results of a study of the plant species present in the diet of rabbits in a similar type of ecosystem (M. C. Reis, P. Beja, M. L. Mathias, pers. comm.).

Concentrations of $n$-alkanes from both faecal and vegetation samples were iteratively compared using a non-negative least-squares optimization routine. The aim of the iterations was to find the proportions of the diet components that minimized the squared deviations between the observed faecal concentrations and the expected faecal concentrations calculated from the $n$ alkane contents in the mixtures of plant samples. The maximum number of dietary components that can be discriminated by using this approach is limited to the number of $n$-alkane markers available, which were 13 in this study. This limitation is overcome by pooling individual plant species into groups, which are then treated as dietary components (Mayes \& Dove, 2000). The least-squares routines used in this study took into consideration that plant species within the grass-forb group could be consumed in different proportions. These were estimated and used to calculate a weighted average $n$-alkane concentration across the group. The procedure is fully described in Martins, Elston et al. (in press).

The least squares optimization algorithm also estimated the amount of diet components, $w_{\mathrm{i}}(\mathrm{kg})$, that needs to be ingested to produce a total faecal output of $1 \mathrm{~kg}$. For each diet, the digestibility value, $D$, was then calculated as follows (Newman et al., 1995):

$$
D=\frac{\sum_{i} w_{i}-1}{\sum_{i} w_{i}}
$$

\section{Statistical analysis}

In order to take account of differences in availability of feeding resources at different collection sites, an estimate of the diet composition was made for each season in both years and for different sites, in terms of the following sets of dietary components:

Set (1) oak seedlings, gum cistus leaves, cereal, regrowth of olive trees, grass-forbs and others (a category that included seasonal food items such as gum cistus flowers and acorns);

Set (2) the same as (1) but without regrowth of olive trees;

Set (3) cork oak seedlings, holm oak seedlings and others.

In addition, in the breeding season, the composition of the diet between years was also studied for 58 collection sites in terms of gum cistus leaves, gum cistus flowers and others. In winter, the presence of acorns justified the study of their importance in the diet. Therefore, the diet composition was described in terms of the following sets of dietary components:

Set (4) oak seedlings, gum cistus leaves, cereal stubble, regrowth of olive trees, oak acorns and grassforbs;

Set (5) as (4) without the regrowth of olive trees.

A more detailed analysis of the importance of the acorns of holm oak and cork oak separately, in relation to other components was undertaken for 40 collection sites.

Estimates of the proportions of vegetation types in the diet were excluded when the error sum of squares of the iterative process did not converge. This occurred in 20 out of the 192 estimates and, as a consequence, not all collection sites are represented in all seasons. Because the final data set was unbalanced, residual maximum likelihood analysis (REML) was used (Horgan \& Hunter, 1993). The dietary components were considered 
Table 1. Herbaceous biomass in relation to density of scrub cover and accessibility to arable crops

\begin{tabular}{|c|c|c|c|c|c|c|c|}
\hline & & \multicolumn{3}{|c|}{ Year 1998} & \multicolumn{3}{|c|}{ Year 1999} \\
\hline & & Breeding & Post-breeding & Winter & Breeding & Post-breeding & Winter \\
\hline \multirow[t]{4}{*}{ Open scrub } & With access to & $175.42^{\mathrm{a}}$ & 57.86 & 49.56 & 117.18 & 52.04 & 19.71 \\
\hline & cereals & $5.10^{\mathrm{b}}$ & 4.10 & 3.76 & 4.56 & 3.66 & 2.81 \\
\hline & Without access & 188.56 & 77.84 & 43.67 & 121.15 & 58.27 & 28.45 \\
\hline & to cereals & 5.19 & 4.25 & 3.69 & 4.72 & 3.98 & 3.33 \\
\hline \multirow[t]{4}{*}{ Dense scrub } & With access to & 113.18 & 32.21 & 29.24 & 46.60 & 25.79 & 11.36 \\
\hline & cereals & 4.74 & 3.58 & 3.30 & 3.80 & 3.14 & 2.37 \\
\hline & Without access & 171.31 & 56.06 & 52.32 & 131.08 & 45.30 & 11.22 \\
\hline & to cereals & 5.13 & 4.01 & 3.91 & 4.87 & 3.80 & 2.00 \\
\hline
\end{tabular}

${ }^{\mathrm{a}}$ Actual mean $\left(\mathrm{g} \mathrm{DM} / \mathrm{m}^{2}\right)$.

${ }^{\mathrm{b}}$ Estimated mean of $\log$ transformed values of biomass availability. SED, standard error of differences.

$\operatorname{SED}($ total $)=0.320 ; \operatorname{SED}($ year $)=0.067 ; \operatorname{SED}($ season $)=0.065 ; \operatorname{SED}($ year $\times$ season $)=0.101 ; \operatorname{SED}($ density of vegetation $)=0.217 ;$ $\operatorname{SED}($ access to arable crops $)=0.217$; $\operatorname{SED}($ density of vegetation $\times$ arable crops $\times$ season $)=0.286$.

as levels of a main effect, and the proportions were logratio transformed in relation to grass-forbs before analysis to ensure independence (Elston, Illius \& Gordon, 1996). Other main effects were year and season. The random effects were the collection site and the time of collection within the season. Besides this multivariate approach, an analysis was undertaken for each component of the diet individually, by considering the proportion of the dietary component as the independent variable after angular transformation.

To examine the relationship between the habitat structure, biomass availability and diet composition, the collection sites were grouped into those dominated either by open vegetation ( $>50 \%$ of the area occupied by arable crop, pasture and/or low scrub) or by dense scrub ( $>50 \%$ of the area occupied by average and tall scrub). They were also classified by whether access to arable crops was available or not. The main effects of density of scrub cover, accessibility to arable crops, year and season and their interactions, on the proportion of cereals, oak seedlings and acorns in the diet were tested. Accessibility to arable crops was excluded from the analysis of the proportion of cereals in the diet since it was assumed that cereals were only present in the diets at collection sites with access to arable crops.

The same type of analysis was performed for the study of the effects of seasonal and spatial variation on herbaceous biomass and dry matter digestibility. A linear multiple regression model was fitted to assess the effect of the proportion of oak seedlings, acorns, regrowth of olive trees and cereals on the dry matter digestibility of the diet after angular transformation (see Elston et al., 1996).

All the statistical analyses were performed using Genstat 5 (Genstat 5 Committee, 1993).

\section{RESULTS}

\section{Herbaceous biomass}

There was a significantly higher herbaceous biomass in
1998 than in $1999\left(F_{1,44}=156.50, P<0.001\right)$ (Table 1$)$. In both years, the biomass was significantly higher in the breeding season than in the post-breeding season and winter $\left(F_{2,44}=413.70, P<0.001\right)$.

The herbaceous biomass was significantly lower in areas with dense scrub than in open areas $\left(F_{1,44}=5.40\right.$, $P<0.05)$, with the lowest values being observed during the winter of $1999\left(F_{2,44}=4.20, P<0.05\right)$.

\section{Seasonal and annual changes in the diet composition}

In the collection sites with regrowth of olive trees (set 1), the diet was generally dominated by cereals (range of proportion in the diet $0.17-0.46$ ) and grass-forbs (range $0.11-0.52$ ) (Table 2). The proportion of oak seedlings and of regrowth of olive trees varied between 0.02 and 0.18 , and 0.02 and 0.21 , respectively. The multivariate analysis showed that the ratios between the consumption of the dietary components in relation to grass-forbs were not significantly different within seasons and years $\left(F_{8,168}=1.36, P>0.05\right)$. The proportion of regrowth of olive trees in the diet was significantly higher in 1999 than in $1998\left(F_{1,28}=7.00, P<0.05\right)$ and it was significantly lower in the post-breeding season than in the other seasons $\left(F_{2,28}=5.90, P<0.05\right)$. There was a higher proportion of grass-forbs in the diet in 1998 than in $1999\left(F_{1,28}=5.20, P<0.05\right)$. The proportion of gum cistus leaves in the diet was significantly higher in the breeding season of 1998 and in the winter of 1999 than in the rest of the seasons in both years $\left(F_{2,28}=6.15\right.$, $P<0.01)$.

In the collection sites without regrowth of olive trees (set 2), the diet was also dominated by cereals and grassforbs (Table 2). During winter, the proportion of cereals in the diet ranged from 0.02 to 0.63 . The proportion of grass-forbs in the diet varied from 0.16 to 0.55 and oak seedlings from 0.10 to 0.21 . There were significant differences in the ratio of the proportion of the dietary components in relation to grass-forbs within years and seasons $\left(F_{6,335}=3.07, P<0.01\right)$. The proportions of gum cistus leaves and oak seedlings in the diet were 
Table 2. Estimated diet composition of rabbits Oryctolagus cuniculus expressed in proportions and in terms of different sets of food items that reflect different accessibility to resources at the collection sites. Estimated means of the angular transformed proportions in the groups, with the SED associated with the annual and seasonal variation. Log-ratio transformed proportions in relation to grass-forbs, with the total standard error of difference (SED)

\begin{tabular}{|c|c|c|c|c|c|c|c|c|}
\hline \multicolumn{2}{|c|}{ Year 1998} & \multicolumn{3}{|c|}{ Year 1999} & \multicolumn{3}{|c|}{ SED } & \\
\hline Set & $\begin{array}{l}\text { Dietary } \\
\text { component }\end{array}$ & Breeding & $\begin{array}{l}\text { Post- } \\
\text { breeding }\end{array}$ & Winter & Breeding & $\begin{array}{l}\text { Post- } \\
\text { breeding }\end{array}$ & Winter & \\
\hline \multirow{18}{*}{$\begin{array}{l}1 \\
(n=41)\end{array}$} & \multirow[t]{3}{*}{ Oak seedlings } & 0.15 & 0.09 & 0.10 & 0.02 & 0.18 & 0.12 & \multirow{3}{*}{8.532} \\
\hline & & $12.95 \dagger$ & 5.96 & 12.90 & 3.62 & 16.15 & 15.58 & \\
\hline & & $-4.23 t$ & -6.16 & -4.39 & -4.61 & -1.01 & 3.45 & \\
\hline & \multirow{3}{*}{$\begin{array}{l}\text { Gum cistus } \\
\text { leaves }\end{array}$} & $0.01^{\circ}$ & 0.00 & 0.00 & 0.00 & 0.00 & 0.03 & \multirow{3}{*}{1.95} \\
\hline & & 4.17 & 2.55 & 1.07 & 1.84 & 0.60 & 6.67 & \\
\hline & & -3.08 & -6.82 & -7.55 & -4.76 & -4.21 & 2.55 & \\
\hline & \multirow[t]{3}{*}{ Cereal } & 0.23 & 0.37 & 0.23 & 0.46 & 0.17 & 0.33 & \multirow{3}{*}{9.816} \\
\hline & & 20.67 & 28.14 & 22.62 & 42.41 & 20.62 & 34.09 & \\
\hline & & -2.24 & -0.71 & -3.12 & 2.11 & -0.39 & 6.08 & \\
\hline & \multirow{3}{*}{ Olive tree } & 0.14 & 0.02 & 0.17 & 0.21 & 0.14 & 0.21 & \multirow{3}{*}{4.283} \\
\hline & & 17.98 & 8.60 & 23.57 & 26.60 & 19.48 & 26.35 & \\
\hline & & -1.13 & -5.36 & -0.84 & 1.36 & 2.68 & 6.32 & \\
\hline & \multirow[t]{3}{*}{ Others } & 0.07 & 0.00 & 0.05 & 0.00 & 0.00 & 0.20 & \multirow{3}{*}{6.569} \\
\hline & & 12.75 & 0.03 & 6.45 & 0 & 0 & 19.34 & \\
\hline & & -1.49 & -8.19 & -5.88 & -6.20 & -4.31 & 2.97 & \\
\hline & \multirow[t]{2}{*}{ Grass-forb } & 0.40 & 0.52 & 0.45 & 0.31 & 0.51 & 0.11 & \multirow{3}{*}{$\begin{array}{l}13.61 \\
2.586\end{array}$} \\
\hline & & 35.51 & 50.25 & 42.06 & 30.27 & 38.04 & 8.64 & \\
\hline & Total & & & & & & & \\
\hline 2 & Oak seedlings & 0.13 & 0.20 & 0.09 & 0.16 & 0.19 & 0.21 & \multirow{3}{*}{6.547} \\
\hline \multirow{14}{*}{$(n=94)$} & & 11.18 & 23.36 & 11.58 & 19.28 & 17.46 & 25.32 & \\
\hline & \multirow{4}{*}{$\begin{array}{l}\text { Gum cistus } \\
\text { leaves }\end{array}$} & -4.98 & 3.60 & -5.26 & -1.64 & -0.08 & -1.29 & \\
\hline & & 0.00 & 0.01 & 0.01 & 0.00 & 0.03 & 0.00 & \multirow{3}{*}{1.311} \\
\hline & & 2.40 & 5.73 & 2.75 & 0.98 & 8.49 & 2.67 & \\
\hline & & -5.11 & 1.93 & -7.06 & -6.56 & 0.63 & -6.13 & \\
\hline & \multirow[t]{3}{*}{ Cereal } & 0.24 & 0.63 & 0.08 & 0.50 & 0.47 & 0.02 & \multirow{3}{*}{6.664} \\
\hline & & 24.19 & 50.68 & 10.13 & 45.13 & 40.35 & 2.89 & \\
\hline & & -1.70 & 6.02 & -5.62 & 1.59 & 3.38 & -7.00 & \\
\hline & \multirow[t]{3}{*}{ Others } & 0.08 & 0.00 & 0.27 & 0.02 & 0.00 & 0.39 & \\
\hline & & 12.62 & 0.00 & 26.63 & 5.58 & 0.07 & 36.08 & 4.200 \\
\hline & & -1.50 & -2.57 & -2.67 & -4.96 & -3.48 & -1.11 & \\
\hline & Grass-forb & 0.55 & 0.16 & 0.55 & 0.32 & 0.31 & 0.38 & \\
\hline & & 49.07 & 16.35 & 50.49 & 29.43 & 26.81 & 37.76 & 8.470 \\
\hline & Total & & & & & & & 1.596 \\
\hline 3 & Cork oak & 0.10 & 0.15 & 0.04 & 0.05 & 0.18 & 0.09 & \\
\hline$(n=107)$ & seedlings & 9.62 & 17.60 & 4.67 & 7.18 & 16.18 & 14.41 & 4.979 \\
\hline & & -6.84 & -4.11 & -7.45 & -6.98 & -5.29 & -3.84 & \\
\hline & Holm oak & 0.06 & 0.02 & 0.08 & 0.08 & 0.02 & 0.11 & \\
\hline & seedlings & 7.214 & 2.642 & 9.259 & 11.757 & 2.431 & 17.431 & 4.053 \\
\hline & & -6.99 & -8.43 & -6.73 & -5.48 & -8.09 & -2.99 & \\
\hline & Others & 0.84 & 0.83 & 0.88 & 0.87 & 0.80 & 0.80 & \\
\hline & & 65.61 & 70.05 & 55.79 & 71.19 & 72.76 & 37.21 & 6.193 \\
\hline & Total & & & & & & & 1.153 \\
\hline
\end{tabular}

significantly lower than those of the other groups in the breeding season of $1998(P<0.05)$. Both in the postbreeding season of 1998 and 1999, the proportion of cereals in the diet was significantly higher than the other groups $(P<0.05)$. In winter 1999 , oak seedlings had the highest proportion in the diet. Individually, the proportion of cereals in the diet in the breeding season increased significantly from 1998 to $1999\left(F_{2,73}=6.90\right.$, $P<0.01)$, and was lower in winter than in the other seasons $\left(F_{2,73}=35.85, P<0.001\right)$. The consumption of grass-forbs was significantly lower in the post-breeding season than in the other seasons, especially in 1998 $\left(\mathrm{F}_{2,73}=5.55, P<0.01\right)$. The proportion of gum cistus leaves in the diet was significantly higher in the postbreeding season than in the other seasons $\left(F_{2,72}=19.80\right.$, $P<0.001)$.

At collection sites where seedlings of both oak species were present (set 3 ), the proportion of holm oak seedlings in the diet varied between 0.02 and 0.11 and was significantly lower in the post-breeding season than in the other seasons $\left(F_{2,82}=7.00, P<0.01\right)$ (Table 2$)$. The proportion of cork oak seedlings in the diet varied 
Table 3. Estimated diet composition of rabbits Oryctolagus cuniculus in winter expressed in proportions and in terms of different sets of food items that reflect different accessibility to resources at the collection sites

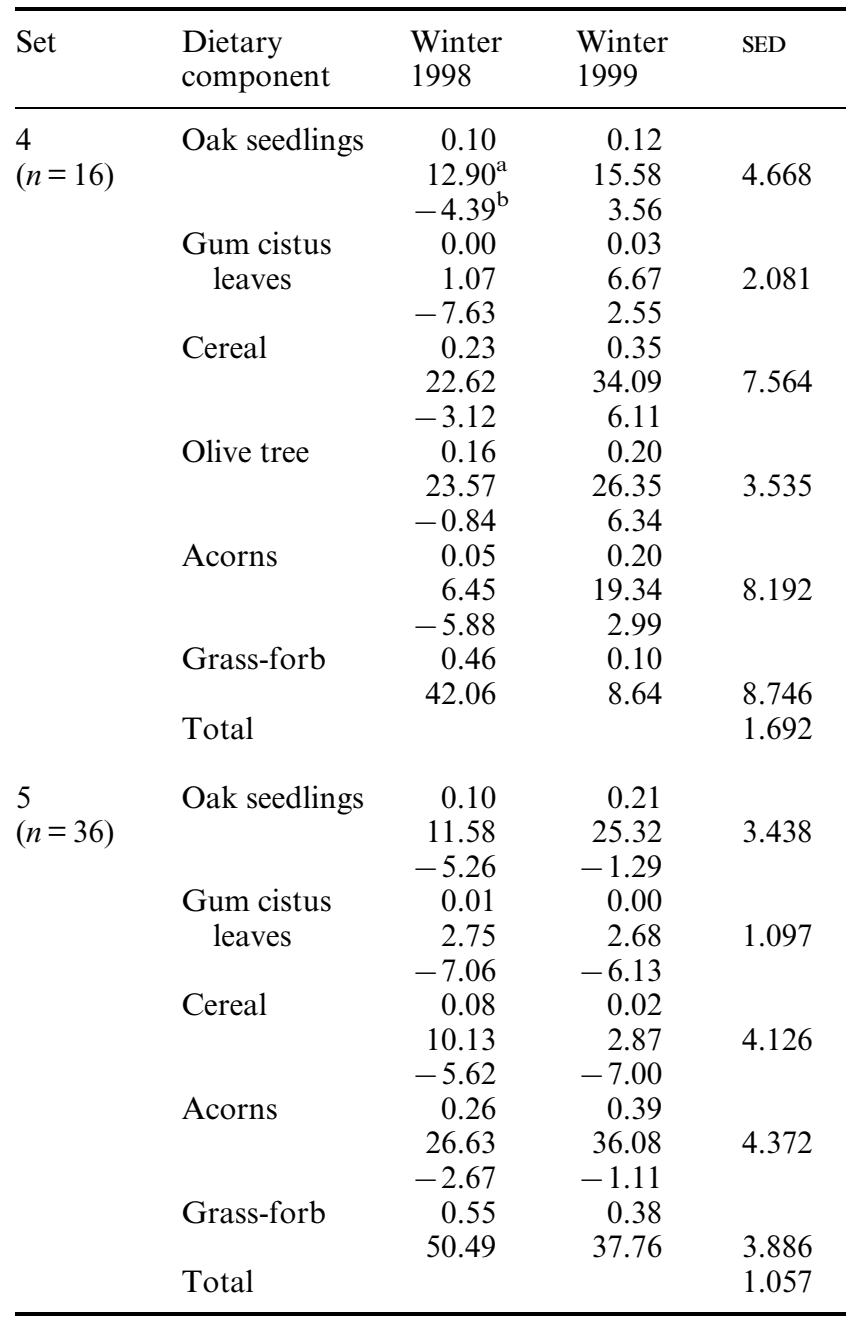

${ }^{\text {a }}$ Estimated means of the angular transformed proportions in the groups, with the SED associated with the annual and seasonal variation.

${ }^{\mathrm{b}}$ Log-ratio transformed proportions in relation to grass-forbs, with the total SED.

between 0.03 and 0.18 and was higher in the postbreeding season than in the other seasons $\left(F_{2,82}=3.09\right.$, $P<0.05)$. The proportion of flowers of the gum cistus

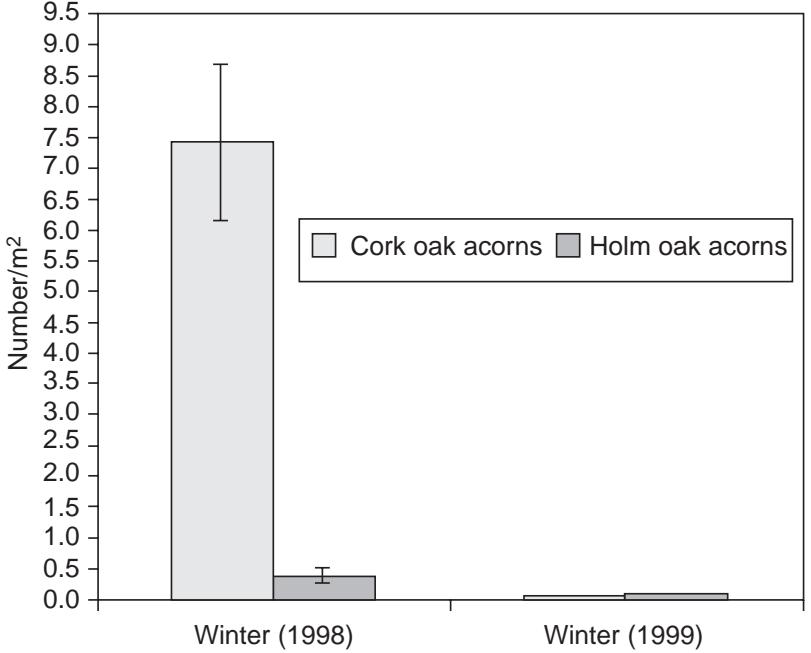

Fig. 1. Number of acorns per $\mathrm{m}^{2}$ in winter, 1998 and 1999.

in the diet in the breeding season was significantly higher in $1998(0.08)$ than in $1999(0.02)\left(F_{2,28}=20.30\right.$, $P<0.001)$.

In winter, in sites where acorns and all the food items were present (set 4), oak seedlings were present in the diet in the range $0.10-0.12$, and cereals in the range $0.23-0.35$ (Table 3). The proportion of acorns in the diet ranged from 0.05 to 0.20 . The proportion of grass-forbs was significantly lower in 1999 (0.11) than in $1998(0.46)$ $\left(F_{1,7}=14.60, \quad P<0.001\right)$, as opposed to gum cistus leaves, which showed the opposite trend $\left(F_{1,7}=7.20\right.$, $P<0.05$ ).

In sites without regrowth of olive trees (set 5), the proportion of acorns in the diet in relation to grassforbs was higher than the other groups in 1998 $(P<0.05)$. In 1999, both acorns and oak seedlings were present in higher proportions than the other groups $\left(F_{3,119}=4.33, P<0.01\right)$. In relation to set 4 , there was an increase in the proportion of acorns in the diet (between 0.27 and 0.39 ) and a decrease in the proportion of cereals (between 0.01 and 0.07). The proportion of oak seedlings in the diet was significantly higher in 1999 than in $1998\left(F_{1,17}=16.00, P<0.001\right)$, as was the proportion of acorns $\left(F_{1,17}=4.70, P<0.05\right)$, whilst the proportion of grass-forbs was significantly lower in 1999 than in $1998\left(F_{1,17}=10.70, P<0.01\right)$.

In terms of acorns of individual oak species, only the

Table 4. Estimated proportion of cereals in the diet of rabbits Oryctolagus cuniculus, in relation to density of scrub cover and accessibility to arable crops

\begin{tabular}{|c|c|c|c|c|c|c|}
\hline & \multicolumn{3}{|c|}{ Year 1998} & \multicolumn{3}{|c|}{ Year 1999} \\
\hline & Breeding & Post-breeding & Winter & Breeding & Post-breeding & Winter \\
\hline \multirow[t]{2}{*}{ Open scrub } & $0.16^{\mathrm{a}}$ & 0.46 & 0.14 & 0.44 & 0.19 & 0.21 \\
\hline & $17.25^{\mathrm{b}}$ & 31.20 & 14.98 & 40.66 & 18.16 & 21.15 \\
\hline \multirow[t]{2}{*}{ Dense scrub } & 0.31 & 0.63 & 0.10 & 0.55 & 0.55 & 0.01 \\
\hline & 28.90 & 48.23 & 12.79 & 48.55 & 47.45 & 2.38 \\
\hline
\end{tabular}

${ }^{a}$ Actual mean of proportions.

${ }^{\mathrm{b}}$ Estimated mean of angular transformed proportions.

$\operatorname{SED}($ total $)=8.569 ; \operatorname{SED}($ season $)=4.135 ; \operatorname{SED}($ year $\times$ season $)=5.624 ; \operatorname{SED}($ den. vegetation $\times$ season $)=6.688$. 
Table 5. Estimated proportion of oak seedlings in the diet of rabbits Oryctolagus cuniculus, in relation to density of scrub cover and accessibility to arable crops

\begin{tabular}{|c|c|c|c|c|c|c|c|}
\hline & & \multicolumn{3}{|c|}{ Year 1998} & \multicolumn{3}{|c|}{ Year 1999} \\
\hline & & Breeding & Post-breeding & Winter & Breeding & Post-breeding & Winter \\
\hline \multirow[t]{4}{*}{ Open scrub } & \multirow{2}{*}{$\begin{array}{l}\text { With access to } \\
\text { cereals }\end{array}$} & $0.21^{\mathrm{a}}$ & 0.18 & 0.14 & 0.04 & 0.15 & 0.16 \\
\hline & & $18.44^{\mathrm{b}}$ & 20.56 & 16.49 & 7.75 & 13.91 & 21.30 \\
\hline & \multirow{2}{*}{$\begin{array}{l}\text { Without access to } \\
\text { cereals }\end{array}$} & 0.00 & 0.94 & 0.00 & 0.22 & 0.00 & 0.12 \\
\hline & & 0.00 & 70.0 & 70.00 & 18.66 & 3.87 & 13.52 \\
\hline \multirow[t]{4}{*}{ Dense scrub } & \multirow{2}{*}{$\begin{array}{l}\text { With access to } \\
\text { cereals }\end{array}$} & 0.11 & 0.14 & 0.08 & 0.21 & 0.28 & 0.23 \\
\hline & & 9.09 & 18.46 & 11.38 & 24.10 & 25.32 & 26.61 \\
\hline & \multirow{2}{*}{$\begin{array}{l}\text { Without access to } \\
\text { cereals }\end{array}$} & 0.00 & 0.10 & 0.08 & 0.10 & 0.45 & 0.26 \\
\hline & & 0.00 & 12.94 & 11.61 & 10.16 & 36.06 & 30.82 \\
\hline
\end{tabular}

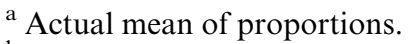

${ }^{\mathrm{b}}$ Estimated mean of angular transformed proportions.

$\operatorname{SED}($ total $)=11.350 ; \operatorname{SED}($ density of vegetation $\times$ year $)=4.597$.

proportion of cork oak acorns in the diet changed significantly, being lower in $1998(0.14)$ than in 1999 (0.29) $\left(F_{1,19}=11.10, P<0.01\right)$. Both cork oak and holm oak acorn availability were higher in winter of 1998 than in winter of 1999 , but only significantly in the cork oak $(P<0.001)$ (Fig. 1).

\section{Influence of the habitat structure on diet composition}

The proportion of cereals in the diet was lower during the winter than in the other seasons, especially in the areas with dense scrub cover $\left(F_{2,35}=9.60, P<0.001\right)$ (Table 4).

The proportion of oak seedlings in the diet changed significantly between years in open areas and in areas dominated by dense scrub, and in opposite directions $\left(F_{1,43}=13.20, P<0.001\right)$ (Table 5). In dense scrub, the proportion of this dietary component was significantly higher in 1999 than in 1998, whilst in open areas it was significantly higher in 1998 than in $1999(P<0.05)$. The proportion of oak seedlings was also significantly higher during the post-breeding season in the open areas without access to arable crops in 1998 than in other seasons in both years $\left(F_{2,43}=6.40, P<0.01\right)$.

The proportion of acorns in the diet was significantly higher in sites with dense scrub cover than in sites with open vegetation $\left(F_{1,53}=5.60, P<0.05\right)$ (Table 6$)$.

\section{Dry matter digestibility}

Digestibility of dry matter was highest when tree seedlings $\left(b=1.16, t_{20}=3.47, P<0.05\right)$ and acorns $(b=1.62$, $\left.t_{20}=2.92, P<0.05\right)$ were present in the diet and lowest when cereals were in the diet $\left(b=-1.93, t_{20}=-4.09\right.$, $P<0.001$ ).

Dry matter digestibility was significantly higher in the breeding season of 1998 and the winter of 1999 than in other seasons in both years $\left(F_{2,41}=20.50, P<0.001\right)$. The structure of the habitat did not significantly affect digestibility of the dry matter (Table 7).
Table 6. Estimated proportion of acorns in the diet of rabbits Oryctolagus cuniculus in relation to density of scrub and accessibility to arable crops

\begin{tabular}{llcc}
\hline & & Year 1998 & Year 1999 \\
\cline { 3 - 4 } & & Winter & Winter \\
\hline Open scrub & With access to & $0.08^{\mathrm{a}}$ & 0.28 \\
& cereals & $11.03^{\mathrm{b}}$ & 26.88 \\
& Without access to & 0.04 & 0.17 \\
& cereals & 4.83 & 17.64 \\
Dense scrub & With access to & 0.35 & 0.45 \\
& cereals & 34.76 & 40.49 \\
& Without access to & 0.15 & 0.19 \\
& cereals & 12.74 & 19.18 \\
\hline
\end{tabular}

${ }^{a}$ Actual mean of proportions.

${ }^{\mathrm{b}}$ Estimated mean of angular transformed proportions. $\operatorname{SED}($ year $)=3.739 ; \operatorname{SED}($ density of vegetation $)=6.914$; $\operatorname{SED}($ access to arable crops $)=6.914$.

\section{DISCUSSION}

The assumption was made that the faeces taken from each collection site reflected the average diets of the individuals belonging to the group of warrens within it. These warrens were associated with one another as a result of juvenile dispersion, environmental heterogeneity (Myers \& Parker, 1965; Künkele \& Von Holst, 1996) and social behaviour (Dunsmore, 1974; Parer, 1977; Daly, 1981). It is, therefore, probable that the individuals of the same group of warrens had access to the same feeding resources and had similar diets.

The number of dietary components whose proportion can be estimated by the $n$-alkane technique is limited to the number of markers available (Dove \& Mayes, 1991). This is a limitation in the use of the $n$-alkane technique in the study of complex diets, since there will be always some subjectivity in the choice of the plant mixtures whose pattern of $n$-alkane concentrations is compared with that of the faecal samples. This subjectivity was reduced by making sure that the plant mixtures were representative of the diet, in both seasonal and spatial terms. Moreover, the diet was studied in terms of functional groups, and the same criteria were used to 
Table 7. Estimated digestibility of dry matter in relation to year, season, density of scrub cover and accessibility to arable crops

\begin{tabular}{|c|c|c|c|c|c|c|c|}
\hline & & \multicolumn{3}{|c|}{ Year 1998} & \multicolumn{3}{|c|}{ Year 1999} \\
\hline & & Breeding & Post-breeding & Winter & Breeding & Post-breeding & Winter \\
\hline $\begin{array}{l}\text { Open } \\
\text { scrub }\end{array}$ & $\begin{array}{l}\text { With access to } \\
\text { cereals } \\
\text { Without access to } \\
\text { cereals }\end{array}$ & $\begin{array}{r}0.60^{\mathrm{a}} \\
60.94^{\mathrm{b}} \\
0.58 \\
58.26\end{array}$ & $\begin{array}{r}0.54 \\
55.51 \\
0.43 \\
42.11\end{array}$ & $\begin{array}{r}0.55 \\
55.56 \\
0.51 \\
51.31\end{array}$ & $\begin{array}{r}0.50 \\
50.10 \\
0.41 \\
41.47\end{array}$ & $\begin{array}{r}0.47 \\
47.00 \\
0.48 \\
48.23\end{array}$ & $\begin{array}{r}0.60 \\
60.63 \\
0.58 \\
57.61\end{array}$ \\
\hline $\begin{array}{l}\text { Dense } \\
\text { scrub }\end{array}$ & $\begin{array}{l}\text { With access to } \\
\text { cereals } \\
\text { Without access to } \\
\text { cereals }\end{array}$ & $\begin{array}{r}0.62 \\
61.81 \\
0.54 \\
54.43\end{array}$ & $\begin{array}{r}0.59 \\
59.54 \\
0.46 \\
45.63\end{array}$ & $\begin{array}{r}0.60 \\
59.77 \\
0.53 \\
53.21\end{array}$ & $\begin{array}{r}0.49 \\
48.55 \\
0.46 \\
46.26\end{array}$ & $\begin{array}{r}0.48 \\
48.05 \\
0.55 \\
54.92\end{array}$ & $\begin{array}{r}0.65 \\
65.40 \\
0.64 \\
64.04\end{array}$ \\
\hline
\end{tabular}

a Actual mean of proportions.

${ }^{\mathrm{b}}$ Estimated mean of angular transformed proportions.

$\operatorname{SED}($ total $)=5.503 ; \operatorname{SED}($ year $)=1.433 ; \operatorname{SED}($ season $)=2.015 ; \operatorname{SED}($ year $\times$ season $)=2.627 ; \operatorname{SED}($ arable crops $\times$ year $)=2.371 ;$ SED $($ arable crops $\times$ year $\times$ season $)=3.837$.

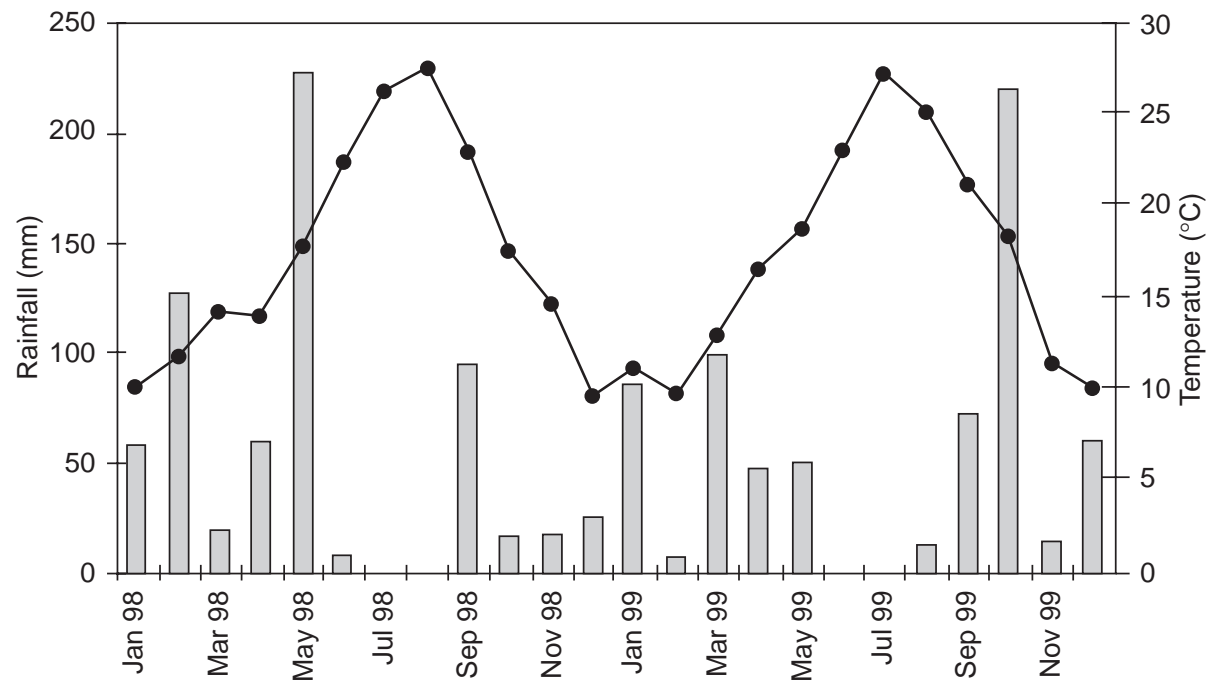

Fig. 2. Mean monthly temperature and total monthly rainfall during the period of study. Bars, rainfall registered in the study area; line, temperature registered in the Meteorological Station of Évora, Portugal.

select, consistently, the plant species for the grass-forbs group. Comparisons between mean estimates of diet composition obtained for different sites and seasons were, therefore, considered to be valid.

The results illustrated the diversity of the diet of the wild rabbit population under study. This has also been observed in other Mediterranean populations of wild rabbit and has been suggested as being a strategy of adaptation to spatial and temporal availability and quality of food resources (Chapuis, 1979; Soriguer, 1988).

The diet was dominated by grass-forbs. When present, cereals were also an important dietary component, but their consumption tended to decrease in winter, a season when they are reduced to stubbles and their nutritional value and availability are low. In the browse component of the diet, the consumption of gum cistus leaves, and flowers in the breeding season, occurred only on a small scale. The regrowth of olive trees, when available, represented an important feeding resource. The consumption of oak seedlings occurred throughout the year and was higher for cork oak than for holm oak in the post-breeding season. It is possible that consumption of adult oak leaves and regrowth from tree stumps occurred (see Fa et al., 1999), but this was not quantified in this study because of its probable small scale and low relevance for management.

Acorns are a valuable resource in winter, especially in areas dominated by dense scrub vegetation. This is true even when their production is compromised by unfavourable weather conditions during spring that kill the flowers (Gysel, 1956), as might have occurred in the study area in 1999 (see Figs 1 \& 2). In sites with access to cereals and regrowth of olive trees, the consumption of acorns in winter was constant from one year to the next. In the rest of the sites, it was higher in 1999 than in 1998, which stresses their role as alternative feeding resources. It may be that the consumption of acorns might have been underestimated, since the husk might have been removed before consumption and the acorn 
itself has low $n$-alkane concentration. The authors know of no data for judging the importance of the consumption of husk.

The higher proportion in the diet of regrowth of olive trees, acorns and oak seedlings in 1999 than in 1998, contrasting with a decrease in the proportion of grassforbs, may have been associated with the observed decrease in primary production of forbs, explained by a lower accumulated rainfall in the breeding season in 1999, particularly during May (Fig. 2). This effect was more accentuated in sites with dense scrub, which for oak regeneration raises two points: (1) the dense scrub might provide protection to seedlings from large herbivores and, therefore, offers a greater availability to rabbits; (2) the low herbaceous biomass availability might also motivate rabbits to increase their searching effort.

Seasonally, the herbaceous biomass availability decreased from the breeding season (end of winter and spring) to the post-breeding season (summer), when competition for food increased, because the population was increasing rapidly as a consequence of reproductive activity (Martins, Barbosa et al., in press). Young plant material that appeared with the first rains at the start of the winter was rapidly consumed, and biomass availability only increased at the end of the winter and spring when there was more consistent rain and higher temperatures. The higher consumption of browse towards the winter might, therefore, reflect a strategy of compensation where a decrease in consumption of grass-forbs, resulting from either reduced availability or quality, is compensated for with a higher intake of other food items (Myers \& Poole, 1963), such as browse. The high content of soluble cell components in browse material allows the maintenance of the quality of the diet. However, because of its high content of secondary compounds, it might also have required consumption of cereals as a detoxification mechanism (Mabry \& Difeo, 1973; Cheeke, 1976; Illius \& Jessop, 1995).

In comparison with the average value of dry matter digestibility found by Soane (1980) of 0.48 and defined as being low, the estimated digestibility of the diet of the studied population was high, with averages per season ranging from 0.54 to 0.77 . The diet composition results suggest that this relative high digestibility is associated with the inclusion of oak seedlings and acorns in the diet.

In general terms, it can be concluded that the population is well adapted to the seasonal variation in quality and quantity of the feeding resources in montado, following strategies to optimize its use to ensure a high quality diet. Although grass-forbs dominated in the diet, the browse component was important throughout the year, and became more important when there was low herbaceous availability, as has also been observed by Homolka (1988) and Mátral, Altbäcker \& Hahn (1998). This is especially relevant in areas with dense scrub.

Some of the conclusions of this study have consequences for the management of wild rabbit populations in agro-forestry systems. The importance of grass-forbs and cereals in the diet justifies the introduction of pastures and crop fields as a food supply. However, it has to be taken into consideration that the quality and digestibility of the arable crops is low at the end of the summer (e.g. CNICN, 1989), when they are also highly grazed by the red deer population present at the study area. The value of introducing areas of crops as a gamekeeping strategy might be mainly to reduce competition from large herbivores. The supply of fodder with higher nutritive value, should therefore be considered, especially in areas of scrub (see CTGREF, 1975). This would not only maintain the body condition of the rabbits and population size, but also decrease the pressure of herbivores on oak natural regeneration. The consumption of regrowth of olive trees was revealed as being important, suggesting that the pruning of olive trees to stimulate regrowth could also provide an important alternative food supply.

Because of the importance of acorns and oak seedlings in the diet (see also Lange \& Graham, 1983), even in the presence of arable crops and high biomass availability, it is suggested that natural oak regeneration should be actively protected with exclosures (see, for example, Klein, Saint-Andrieux \& Ballon, 1989).

\section{Acknowledgements}

This study was funded by European Commission Programme PRAXIS XXI (BD9396/96). We are grateful to Direcção Geral de Florestas for allowing the data collection at Tapada Pequena de Vila Viçosa, and to Dr A. J. Duncan and to an anonymous referee for kindly commenting on the manuscript.

\section{REFERENCES}

Alves, R., Borralho, R., Carvalho, C. R. \& Bugalho, J. (1995). Uso sensato no espaço rural alentejano. Rev. Ciênc. Agrár. 18(4): 51-66.

Alves, P. C. \& Moreno, S. (1996). Estudo da reprodução do coelho-bravo (Oryctolagus cuniculus) em Portugal. Rev. Flor. 9: 149-166.

Barrreto, A. \& Carvalho, C. R. (1993). A avaliação de projectos de investimento em zonas de caça turística. Rev. Flor. 6: 31-41.

Bhadresa, R. (1977). Food preferences of rabbits Oryctolagus cuniculus L. at Holkham sand dunes, Norfolk. J. appl. Ecol. 14: 287-291.

Bugalho, M. (1999). The foraging behaviour of red deer (Cervus elaphus) in a mediterranean environment. $\mathrm{PhD}$ thesis, University of Aberdeen, Scotland.

Chapuis, J. L. (1979). Le régime alimentaire du lapin de garenne, Oryctolagus cuniculus (L. 1758) dans deux habitats contrastés: une lande bretonne et un domaine de l'Ile de France. Thèse 3e cycle, University of Rennes.

Chapuis, J. L. \& Forgeard, F. (1982). Liaisons entre les choix alimentaires du lapin de garenne, Oryctolagus cuniculus (L.), et la phénologie de la végetation sur les pelouses et les landes incendiés. Acta Oecol. 3: 495-510.

Cheeke, P. R. (1976). Nutrition of the domestic rabbit. Lab. Anim. Sci. 26: 654-658. 
Chen, W., Scott, J. M., Blair, G. J. \& Lefroy, R. D. B. (2000). Using plant cuticular alkanes to study plant-animal interactions on pastures. Can. J. Anim. Sci. 79: 553-556.

CNICN (1989). Aménagement des territoires de chasse. Grand Gibier 15: 1-15.

CTGREF (1975). Aménagement des territoires de chasse au petit gibier. Note Téch. Forest. 28: 1-87.

Daly, J. C. (1981). Effects of social organisation and environmental diversity on determining the genetic structure of a population of the wild rabbit, Oryctolagus cuniculus. Evolution 35: 689-706.

Dove, H. \& Mayes, R. W. (1991). The use of plant wax alkanes as marker substances in studies of the nutrition of herbivores: a review. Aust. J. Agric. Res. 42: 913-952.

Dove, H. \& Moore, A. D. (1995). Using a least-squares optimisation procedure to estimate botanical composition based on the alkanes of plant cuticular wax. Aust. J. Agric. Res. 46: $1535-1544$.

Dove, H., Mayes, R. W. \& Freer, M. (1996). Effects of species, plant part and age on the $n$-alkane concentrations in the cuticular wax of pasture plants. Aust. J. Agric. Res. 47: 1333-1347.

Dunsmore, J. D. (1974). The rabbit in Subalpine south-eastern Australia. I. Population structure and productivity. Wildlife Res. 1: 1-16.

ESRI (1995). ARCVIEW GIS Manual version 3. 1. Redlands, CA: Environmental Systems Research Institute.

Elston, D. A., Illius, A. W. \& Gordon, I. J. (1996). Assessment of preference among a range of options using log ratio analysis. Ecology 77: 2538-2548.

Fa, J. E., Sharples, C. M. \& Bell, D. J. (1999). Habitat correlates of European rabbit (Oryctolagus cuniculus) distribution after spread of RVHD in Cadiz Province, Spain. J. Zool. (Lond.) 249: 83-96.

Genstat 5 Committee (1993). Genstat 5 reference manual. Oxford: Claredon Press.

Gibb, J. A. (1993). Sociality, time and space in a sparse population of rabbits (Oryctolagus cuniculus). J. Zool. (Lond.) 229: 581-607.

Gysel, L. W. (1956). Measurement of acorn crops. Forest Sci. 2: $305-313$.

Homolka, M. (1988). Diet of the wild rabbit (Oryctolagus cuniculus) in an agrocenosis. Folia Zool. 37: 121-128.

Horgan, G. W. \& Hunter, E. A. (1993). Introduction to REML for scientists. GENSTAT 5. 3. Scottish Agricultural Statistics Services.

Illius, A. W. \& Jessop, N. S. (1995). Modelling metabolic cost of allelochemical ingestion by foraging herbivores. J. Chem. Ecol. 21: 693-719.

Joffre, R., Rambal, S. \& Ratte, J. P. (1999). The dehesa of southern Spain and Portugal as a natural ecosystem mimic. Agroforest. Syst. 45: 57-59.

Klein, F., Saint-Andrieux, C. \& Ballon, P. (1989). Quelles protections pour les plants forestiers? Bull. Mens. Office Natl Chasse 141: $31-35$.

Künkele, J. \& Von Holst, D. (1996). Natal dispersion in the European wild rabbit. Anim. Behav. 51: 1047-1059.

Lange, R. T. \& Graham, C. R. (1983). Rabbits and the failure of regeneration in Australia arid zone Acacia. Aust. J. Ecol. 8: 377-381.

Mabry, T. J. \& Difeo, D. R. Jr (1973). The role of secondary plant chemistry in the evolution of the Mediterranean scrub vegetation. In Mediterranean type ecosystems: 121-156. di Castri, F. \& Mooney, H. (Eds). Berlin: Springer Verlag.

Martin, P. \& Bateson, P. (1993). Measuring behaviour. An introductory guide. 2nd edn. Cambridge: Cambridge University Press.

Martins, H., Elston, D. A., Mayes, R. W. \& Milne, J. A. (In press). Assessment of the use of $n$-alkanes as markers to describe the complex diets of herbivores. J. Agric. Sci.

Martins, H., Barbosa, H., Hodgson, M., Borralho, R. \& Rego, F. (In press). Effect of vegetation type and environmental factors on European wild rabbit (Oryctolagus cuniculus L.) counts in a Southern Portuguese montado. Acta Theriol.

Mátral, K., Altbäcker, V. \& Hahn, I. (1998). Seasonal diet of rabbits and their browsing effect on juniper in Bugac Juniper Forest (Hungary). Acta Theriol. 43: 107-112.

Mayes, R. W., Lamb, C. S. \& Colgrove, P. M. (1986). The use of dosed and herbage $n$-alkanes as markers for the determination of herbage intake. J. Agric. Sci. 107: 161-170.

Mayes, R. W., Dove, H., Chen, X. B. \& Guada, J. A. (1995). Advances in the use of faecal and urinary markers for measuring diet composition, herbage intake and nutrient utilisation in herbivores. In Recent developments in the nutrition of herbivores: 381-406. Journet, M., Grenet, E., Farce, M. T., Thériez, M. \& Demarquilly, C. (Eds). Paris: INRA.

Mayes, R. W. \& Dove, H. (2000). Measurement of dietary nutrient intake in free-ranging mammalian herbivores. Nutr. Res. Rev. 13: 107-138.

Moreno, S. \& Villafuerte, R. (1995). Traditional management of scrubland for the conservation of rabbit and their predators in Doñana National Park Spain. Biol. Conserv. 73: 81-85.

Moreno, S., Villafuerte, R., Queirós, F. \& Jordán, G. (1996). Qual é o melhor período do ano para realizar repovoamentos de Coelho-bravo (Oryctolagus cuniculus)? Rev. Flor. 9: 267-275.

Myers, K. \& Parker, B. S. (1965). A study of the biology of the wild rabbit in climatically different regions in East Australia I. Pattern of distribution. Wildl. Res. 10: 1-32.

Myers, K. \& Poole, W. E. (1963). A study of the biology of the wild rabbit, Oryctolagus cuniculus (L.), in confined populations. IV. The effects of rabbit grazing on sown pastures. J. Ecol. 51: 435-451.

Newman, J. A., Thompson, W. A., Penning, P. D. \& Mayes, R. W. (1995). Least-squares estimation of diet composition from $n$-alkanes in herbage and faeces using matrix mathematics. Aust. J. Agric. Res. 46: 793-805.

Palomares, F., Calzada, J. \& Revilla, E. (1996). El manejo del habitat y la abundancia de conejos: diferencias entre dos areas potencialmente identicas. Rev. Flor. 9: 201-210.

Parer, I. (1977). The population ecology of the wild rabbit, Oryctolagus cuniculus L., in a Mediterranean type climate in New South Wales. Wildl. Res. 4: 171-205.

Roberts, G. \& Nunes da Silva, J. (2000). Conserving sustainable agriculture and its rich wildlife in the Beira Baixa and Alentejo regions of Portugal. La Cañada 12: 14-16.

Rosário, L., Marques, A., Bugalho, M. \& Lopes, F. (1983). Plano de utilização da Tapada Pequena de Vila Viçosa. Lisbon: Ministério da Agricultura Comércio e Pescas, Direcção Geral das Florestas.

Salt, C. A., Mayes, R. W. \& Elston, D. A. (1992). Effects of season, grazing intensity and diet composition on the radiocaesium intake by sheep on re-seeded hill pasture. J. appl. Ecol. 29: $378-387$.

Salt, C. A., Mayes, R. W., Colgrove, P. M. \& Lamb, C. S. (1994). The effects of season and diet composition on the radiocaesium intake by sheep grazing on heather moorland. J. appl. Ecol. 31: 125-136.

Soane, G. A. (1980). Food selection by the rabbit. PhD thesis, University of Wales.

Soriguer, R. C. (1988). Alimentación del conejo (Oryctolagus cuniculus L. 1758) en Doñana. SO, España. Doñana Acta Vertebr. 15: 141-150.

Thompson, S. K. (1992). Sampling. Wiley series in probability and mathematical statistics. New York: Wiley.

Williams, O. B., Wells, T. C. E. \& Wells, D. A. (1974). Grazing management of woodland fen: seasonal changes in the diet of cattle and rabbits. J. appl. Ecol. 11: 499-516. 